\title{
POETIC JUSTICES AND THE LEGALITIES OF LOVE
}

Sandra Petersson*

This article was presented as a Victoria University of Wellington Centennial Lecture during Law Festival Week in 1999. The article surveys the use of poetry in written judgments. The author suggests that judges most often quote poetry as a rhetorical device, for one of three common purposes: (a) to comment on the parties or facts; (b) to divert from the legal analysis; (c) to introduce the judgment. In addition to these rhetorical purposes, judges also resort to poetry when required to address the topic of love. In assessing whether to recognise a legal tie between parties in a relationship, love is not an express requirement. Lacking a legal definition of love, judges turn to poets.

\section{INTRODUCTION}

\author{
Law, says the judge as he looks down his nose, \\ Speaking clearly and most severely, \\ Law is as I've told you before, \\ Law is as you know I suppose, \\ Law is but let me explain it once more, \\ Law is The Law.
}

$$
\text { WH Auden }{ }^{1}
$$

As I am to talk about what judges do with poetry, I thought it was only fair to begin with an example of what poets do with judges. My opening quotation is from "Law Like Love" by

* Lecturer in Law, Victoria University of Wellington. I would like to thank Jason Epps-Eades for making this article possible. This paper was written for oral presentation. Though it has been edited somewhat for publication, it retains its primary character as an oral text, as do the poems and judgments which are its subject.

1 WH Auden "Law Like Love" in Collected Poems (Vintage International, New York, 1991) 262-264. 
WH Auden, a poem that not only discusses judges, but my two other themes as well - law and love.

Judges and poetry. Law and love. Two of these enrich the soul and the soul improves the other two. Judges have themselves recognised this connection. For example, once upon a time in a distant land, a young boy named Paul wrote to a judge to inquire how best to prepare to become a lawyer. The judge wrote back: ${ }^{2}$

My Dear Paul

No one can be a truly competent lawyer unless he is a cultivated man. ... The best way to prepare for the law is to come to the study of law as a well-read person. ... No less important for a lawyer is the cultivation of the imaginative faculties by reading poetry, seeing great paintings ... and listening to great music. Stock your mind with the deposit of much good reading, and widen and deepen your feelings by experiencing vicariously as much as possible of the wonderful mysteries of the universe, and forget all about your future career.

With good wishes,

Felix Frankfurter

From Justice Frankfurter's advice, one might conclude that the relationship between reading poetry and writing judgments was like learning to ride a bicycle before learning to drive a car. But if the metaphor holds then some judges must be horrific drivers - the frequent use of poetry by some judges goes beyond the occasional resort to hand signals and suggests that they prefer the footpath. Perhaps a more accurate description was that offered by Lord Denning who considered "the classics of English history and literature" to be among the tools of his trade. ${ }^{3}$ Anyone with a passing familiarity with Lord Denning's judgments knows that he wielded these tools with an artisan's skill.

2 Felix Frankfurter "Advice to a Young Man Interested in Going into Law" in Ephraim London (ed) The World of Law: The Law as Literature (Simon \& Schuster, New York, 1960) 725.

3 Lord Denning Landmarks in the Law (Butterworths, London, 1984) 369. 
However, most judges do not quote poetry when writing judgments. Poetry is not precedent, as the American judge Justice Steakley once noted in dissent: ${ }^{4}$

The precedential or supportable value of the writings upon which the majority relies would seem questionable, ie Shakespeare, John Milton, Alexander Pope, Robert Burns, William Wordsworth, Isaac Watts, Lord Byron, Thomas Percy, Samuel Taylor Coleridge, Alfred Lord Tennyson, Henry David Thoreau, John Ruskin, John Davidson, and Rudyard Kipling. I suggest our own writings are more in point.

It was, of course, exceptional for these authors to have been quoted jointly but not so unusual to find them cited severally. But as Justice Steakley warned legal authorities carry more value. So why bother with poetry?

It is my purpose to discuss why and for what purposes judges mix poetry and law. The "why" is easily dealt with. The incorporation of poetry in judgment writing is, for the most part, a matter of style. Poetic quotations are just one of a variety of rhetorical devices used by judgment writers. The purposes for which judges quote poetry are also relatively straightforward. I will begin my analysis by reviewing three purposes for which judges quote poetry. The three more common purposes for using poetry as a rhetorical device are as:

- a comment on the parties or facts of the case;

- a diversion from the legal analysis; or

- $\quad$ an introduction to the overall judgment.

I will illustrate each of these three common purposes with examples from New Zealand judgments. Having reviewed how judges use poetry as a rhetorical device, I will then go on to discuss instances where judges rely on poetry to provide knowledge that they themselves lack - that is knowledge about love. I will conclude with a suggestion as to how judges might improve their performances in this area.

4 Standard Fire Insurance Co v Reese (1979) 584 SW 2d 835, 842 (Texas SC). Similar disapproval of literary references was voiced by Giles J in Reid v Comptroller of Customs (11 December 1998) unreported, High Court, Auckland, AP 179/98, 10: "There are occasions where a display of one's knowledge of matters literary may add something to a judgment but, by and large, it is the responsibility of a judicial officer to deliver a judgment in objective, sensible and restrained terms which addresses the substance of the case, the substance of the evidence and the law, A judgment is not to be treated as an opportunity to demonstrate one's abiding knowledge of our written literary history." Thanks to Amy Cecil-Gibson for bringing Reid to my attention. 
Two additional points deserve clarification before I begin my analysis. First, the examples I refer to are all by male poets, most frequently Shakespeare. I have not found any serious instances of female poets being quoted in either Commonwealth or American judgments though Elizabeth Barrett Browning is frequently parodied when judges feel the need to "count the ways" of something. I attribute the absence of quotations from women poets to the neglect of women's writing in traditional literature studies generally. ${ }^{5}$ Second, in order to simplify my research, I made the decision to overlook judicial references to any works by Lewis Carroll. There are more than 1000 references to Carroll or to Alice's Adventures in Wonderland in American cases alone, a phenomenon that is perhaps best labelled as "curiouser and curiouser", and one that I think merits an entirely separate research project. ${ }^{6}$

\section{COMMENTS ON THE PARTIES OR FACTS}

The first of the three common uses of poetry as a rhetorical device that I have identified is to use a poetic quotation to comment on the parties or the facts. These are usually included as short pithy statements, by way of summary. For example, in assessing a wife's attitude to her husband, Judge Ryan noted: ${ }^{7}$

The bitterness which is evident [between them] clearly gives Mrs DY some subconscious pleasure;

to use the words of Lord Byron, "hatred is the lasting pleasure", and those words can be adopted in toto in this case as far as Mrs DY's attitude towards Mr DY is concerned.

In a more favourable vein, Hillyer $\mathrm{J}$ in assessing whether or not the Hibbs' family had a claim for compensation from the deceased's estate in the case of Re Archer concluded as follows: ${ }^{8}$

There would be no doubt but that there was a warm and almost family-like relationship between Mrs Archer and the Hibbs. ... In my view, the Hibbs' services are not confined to mowing lawns or cutting hair. Milton has put it inimitably:

5 On the exclusion of women's writing as literature, see for example Virginia Woolf A Room of One's Own (Bloomsbury Publishing Ltd, London, 1993) and Dale Spender Mothers of the Novel: 100 Good Women Writers Before Jane Austen (Pandora, London, 1986).

6 In contrast, there are only about 200 references to Carroll or Alice in Commonwealth cases (Lexis COMCAS database).

$7 \quad$ DYv DY (1985) 3 NZFLR 446, 447 (Fam).

8 Re Archer [1990] 3 NZLR 737, 743 (HC) quoting John Milton "On His Blindness" (Sonnet 19). 
Thousands at his bidding speed and post o'er land and ocean without rest

They also serve who only stand and wait.

\section{DIVERSIONS FROM THE LEGAL ANALYSIS}

The second common use of poetic quotations is in the judge's analysis of the law. Justice Steakley's earlier concern that literature has little value as precedent is, in practice, overcautionary. The closest use of literature as precedent that I have encountered are the tongue-incheek references to the fictional case of Jarndyce v Jarndyce, the centre-piece of Charles Dickens' Bleak House. ${ }^{9}$ Rather, when judges quote poetry within their legal analysis, it tends to be as a diversionary tactic, though loosely connected to the legal question at hand. These loose legal connections usually fall into one of two categories, either to determine the meaning of a word or to underscore societal values.

\section{A Meanings of Words}

I turn first to the category of using poetic quotations to determine the meaning of a word. Literary sources are not infrequently invoked in interpreting legislation - possibly because generations of law students have been trained to turn to the Oxford English Dictionary which provides a ready source of quotations to illustrate the meaning of each entry. For example, in considering whether it was "expedient" to require the natural father's consent to a child's adoption, Judge Inglis noted the dictionary's reference to Richard III, where Shakespeare used "expedient" to mean "useful, politic, as opposed to just or right". ${ }^{10}$ Judge Inglis, I think quite wisely, rejected Richard III as authority on this point - or on any matter relating to the treatment of fatherless children I would suggest.

Literature is also useful in approaching the meaning of less common words. For example, in Mackintosh $v$ Limmer Gresson J had to determine the meaning of the word "offal" in response to an offence under the Meat Regulations 1940. The regulations did not define "offal" - I suspect because no one wanted to think about what it really was. Gresson J made a

9 For example see Irvine v Public Trustee [1989] 1 NZLR 67, 71 (CA) per Cooke P.

10 Application by GN (adoption) [1991] NZFLR 513, 519 (Fam) quoting William Shakespeare Richard III, I:ii:217. 
diversionary resort to less squeamish times for assistance, quoting both Shakespeare and Milton: ${ }^{11}$

The word ["offal"] is well understood and of great antiquity: see for example Shakespeare's Merry

Wives of Windsor:

Have I lived to be carried in a basket like a barrow of butcher's offal, to be thrown in the

Thames?

and Milton's Paradise Lost:

Till cramm'd and gorg'd, nigh burst with suckt and glutted offal.

\section{B Societal Values}

The second category of literary diversion from the legal analysis is to underscore perceived societal values. And here I ask your indulgence for one prose quotation, rather than a poem. For example, in Willis $v$ Castelein Williams $\mathrm{J}$ had to consider a home-owner's liability to a subsequent purchaser for do-it-yourself home improvements. He stated: ${ }^{12}$

[I]t is pertinent to note that many early settlers in New Zealand were constrained by the prevailing circumstances to build their own dwellings. ... The continuing "do it yourself" tradition seems to indicate that many New Zealanders follow Henry David Thoreau in asserting the therapeutic value of individual creativity. He said in Walden:

There is some of the same fitness in a man's building his own house that there is in a bird's building its own nest. Who knows but if men constructed their own dwellings with their own hands, and provided food for themselves and families simply and honestly enough, the poetic faculty would be universally developed, as birds universally sing when so engaged?...

\section{INTRODUCTIONS TO THE JUDGMENT}

The third purpose of poetic quotations is to introduce a judgment. It may seem a bit illogical to consider introductory quotations last. However, in the best examples, the quotation is used not as an isolated introduction to the case but also to help focus the issue before the

11 Mackintosh v Limmer [1960] NZLR 302, 304 (SC) quoting William Shakespeare The Merry Wives of Windsor III:v:5 and John Milton Paradise Lost X:633. See also Taita Hotels Ltd v Spelman [1963] NZLR 206, 209 (SC) per McGregor J, quoting William Shakespeare on the meaning of "still".

12 Willis v Castelein [1993] 3 NZLR 103, 125 (HC) quoting Henry David Thoreau Walden (1854). 
court - just as a skilled essayist would weave an introductory quotation throughout the text to establish its tone. As such, introductory quotations warrant more detailed comment. For example, in Re Ciminiello Hardie Boys J began as follows: ${ }^{13}$

This judgment should be prefaced with a text, slightly misapplied from Shakespeare: "Such stuff as dreams are made of". For it is said that the applicant dreamed that horse 16 would win. Horse 16 was backed. There was an initial investment of $\$ 98$. The total gross winnings were over $\$ 100,000$.

In most insolvency appeals, the odds are against a judge being able to craft such an introduction. However, Hardie Boys's J appropriation of Shakespeare not only provided a light-hearted introduction but also allowed him to focus on the issue to be decided. With respect to the unlikely facts he later noted: ${ }^{14}$

The trap [in considering the evidence] is that the whole matter raises disbelief. How could so much money have been won so quickly with so little? But the fact is that it was. ... all that really remains to be decided is the source of the $\$ 98$.

Similarly in Balfour $v$ Attorney-General another quotation from Shakespeare was used to introduce the case and to focus the issue, again by Hardie Boys J. The case concerned a rumoured allegation of homosexuality that had been placed on Mr Balfour's personal file with the Department of Education. Mr Balfour claimed the rumour had prejudiced his teaching employment prospects. After a brief reference to the result in the case Hardie Boys J began the third paragraph of the judgment with a quotation from Henry IV Part Two: ${ }^{15}$

Rumour is a pipe,

Blown by surmises, jealousies, conjectures,

And of so easy and so plain a stop

That the blunt monster with uncounted heads,

The still-discordant wavering multitude

Can play upon it.

13 Re Ciminiello [1981] 2 NZLR 495, 496 (HC) quoting William Shakespeare The Tempest IV:i.

14 Re Ciminiello above $\mathrm{n} 13,501$.

15 Balfour v Attorney-General [1991] 1 NZLR 519, 521 (CA) quoting Henry IV Part Two, Introduction. 
The pipe of rumour, he concluded, had played a damning "tune of homosexuality" for Mr Balfour's career though ultimately the Court was not able to find redress for Mr Balfour's financial loss. ${ }^{16}$

Those then are three of the more common purposes for which judges incorporate poetic quotations into their judgment writing - as a comment on the parties, as a diversion in the legal analysis, and, on rarer occasions, as an introduction to the judgment and means of setting its tone. The quotations have related to such things as dreams, rumour, servitude, expediency, offal, and home repair - all things which we would reasonably expect judges to know something about themselves, things that they could have expressed in their own words.

However, not all instances of poetic quotations are merely for rhetorical embellishment. Sometimes judges must rely on poetry to provide knowledge that they themselves lack. As far as I can see, love is one of those things that judges know little about (at least in their professional capacities). I now explain how, when it comes to matters of love, poetic quotations are not just a rhetorical device but in fact provide evidence as to the existence and nature of love.

\section{POETRY AS EVIDENCE? (A NON-RHETORICAL QUESTION)}

\section{A Why Judges Know Nothing About Love}

To explain how I arrive at the conclusion that judges know nothing about love, I will begin by discussing marriage and relationships in the nature of marriage.

One of the first rules that a writer learns is to write about what you know from personal experience. One of the first lessons that a lawyer learns is that you can do many things with a rule. Once you make it, you can break it, or promulgate it. You can bend it, amend it or bring to an end it. You can adore or abhor it. Or, as in this case, ignore it.

Thus having gotten the requirement of personal experience out of the way, there are no further bars to a spinster, such as myself, talking about marriage and relationships in the nature of marriage. Indeed, by traditional legal standards, my qualifications to speak on the subject are thereby improved - I am a neutral and objective third party. However, for those of

16 Balfour v Attorney-General above n 15, 521. 
you harbouring concerns about postmodern subjectivity, I must confess that I was raised by married people.

Let me now summarise, neutrally and objectively (and briefly), what the law says about marriage and relationships in the nature of marriage.

In Law School, I learned that the definitive definition of marriage had been set down in England in 1866 by the learned judge, Wilde J. I was taught that the Temple of Marriage rested upon four pillars. Marriage was: ${ }^{17}$

The voluntary union for life of one man and one woman, to the exclusion of all others.

Of course this was quickly reduced to three pillars as the next topic we discussed in class was divorce. So there were then only three pillars to study for the exam: a voluntary union, one man and one woman, to the exclusion of all others.

"But what about love?" I wondered, as I studied.

"Not an express legal requirement for marriage" the law books said.

"But surely love must have something to do with it?" I continued to puzzle. "Perhaps there would be evidence of love in relationships in the nature of marriage, that is in un-marriagelicensed relationships where there was no legal paperwork to obscure the existence or nonexistence of love."

Back then to the law books for an objective and neutral consideration of relationships in the nature of marriage. I found that the definitions were much more complex - their elements were so numerous as to suggest an analogy to tent poles rather than pillars. But surely definitions that were that complex must refer somewhere to love? But alas no. The list of factors a judge would consider included such important things as whether the parties lived together, whether they had sex, whether they shared household chores and expenses, and whether they were committed to the relationship for the foreseeable future. ${ }^{18}$ But when it came down to love, the only thing on the list that was even close was whether the parties gave each other emotional support and companionship. The same reasons my Grandma would give to convince you to buy a dog instead of a cat.

17 Hyde v Hyde (1866) LR 1 P \& D 130, 133.

18 For a list of factors courts commonly consider see Thompson v Department of Social Welfare [1994] 2 NZLR 369, 373 (CA) per Tipping J. 
So we must conclude that the law is not concerned with love but only with recognising legal ties between individuals.

However, I do not want to be taken as suggesting that we should criticise judges for not appearing to know anything about love. It is an occupational hazard of their job. Marriages and relationships usually only end up before a judge when they are coming to an end. Faced with unhappy people whose dreams of love have faded, it would be rubbing salt in the wound were judges to bring up the subject of love.

As judges, therefore, do not get much practice in talking about love, when the opportunity does arise, they are somewhat ill-prepared. And this is why they have to call on the expertise of poets. Recall that Justice Frankfurter's advice to young Paul was to:

Stock your mind with the deposit of much good reading, and widen and deepen your feelings by experiencing vicariously as much as possible of the wonderful mysteries of the universe.... [my emphasis]

However, it would seem that not all judges were so well-advised as children. At least when it comes to the vicarious experience of love, the stock of good reading that they call upon is somewhat limited. Again and again, judges resort to one single poem for assistance with the topic of love.

I now review a few cases where judges have had the opportunity to approach the subject of love. These are not the usual cases where the parties find themselves before a judge when their relationship is ending. Rather, these are cases where the parties have come before the judge so that their relationship may begin - cases where the judge has to decide if the law recognises a marriage between them. And they are cases that all quote from the same poem.

\section{B Marriages of True Minds: Judicial Use of Shakespeare's Sonnet CXVI}

Many of you, maybe even most of you, will have been to a wedding that included Shakespeare's Sonnet 116 as one of the readings. I have twice been invited to weddings to read the Bard's well-known poem that begins:

Let me not to the marriage of true minds

Admit impediments; love is not love

Which alters when it alteration finds,

Or bends with the remover to remove. 
It is, therefore, oddly fitting that judges quote these same lines in the pronouncement of whether the parties may be husband and wife.

\section{Ex parte Suzanna}

The first case to consider is Ex parte Suzanna, an American case from the early 1900s. ${ }^{19}$ The case concerned whether Sabina Suzanna was the legal wife of Manuel Gomes. Miss Suzanna had been present when the marriage ceremony was performed in Portugal. However, $\mathrm{Mr}$ Gomes was in Philadelphia at the time. The marriage had taken place by proxy, which was legal in Portugal, but whose status had not yet been considered under American law.

Lowell $\mathrm{J}$, in trying to establish the distinction between a marriage ceremony and the relationship of marriage, noted that: ${ }^{20}$

... distinction is brought out by two quotations from Shakespeare. Hamlet says:

Thrift, thrift, Horatio! the funeral-baked meats

Did coldly furnish forth the marriage tables.

an instance of the first meaning. In one of the sonnets this verse occurs:

Let me not to the marriage of true minds

Admit impediments; love is not love

Which alters when it alteration finds.

an instance of the second meaning.

To fit these examples into my earlier classification of how judges use poetry, they are both examples of using poetry to determine the meaning of a word - in this case, to highlight the distinction between two meanings of the single word "marriage".

I would also like to suggest that it is significant that Sonnet 116 was not used as a comment on the parties. There is nothing in the facts of the case to indicate that Miss Suzanna and $\mathrm{Mr}$ Gomes had ever met. It would appear to have been an arranged marriage for immigration purposes. Indeed, the case came to court because Miss Suzanna had been detained by immigration authorities upon her arrival in the United States. She herself had filed the petition

19 Ex parte Suzanna (1924) 295 F 713 (Mass DC).

20 Ex parte Suzanna above n 19, 715 (Mass DC) quoting Shakespeare Hamlet I:ii and "Sonnet CXVI" 1l 1-3, and also Byron "Childe Harold" canto 3, stanza 21. 
for habeas corpus and the judgment makes no reference to affidavits or supporting evidence advanced by Mr Gomes. Thus it would seem that the relationship between Suzanna and Gomes was, itself, not likely one of true minds.

\section{In the matter of Keith Ogilvie}

The next alleged true minds case I will consider is the Matter of Keith Ogilvie, an American case from 1975. ${ }^{21}$ Judge Edelstein began with the quotation "Let me not to the marriage of true minds / Admit impediments." However, this is not an instance of an introductory quote as I have discussed in my earlier review. The quotation has no real association with the judgment other than that both deal with marriage.

The issue in the Ogilvie case was whether the Court could waive the statutory waiting period to allow the parties to marry within 10 days of taking their blood tests. The legislation allowed the Court to waive the waiting period on the bride's application, but made no similar provision for the groom to apply. Mr Ogilvie claimed that this was sex-based discrimination.

As the basis of Mr Ogilvie's claim was that the legislation was discriminatory and invalid, few facts were needed to establish his claim. It could be that this was a true case for the marriage of true minds - but on the facts all that we can safely conclude is that it was a marriage in a true hurry. Judge Edelstein's quotation of Sonnet 116, therefore, cannot be taken as a comment on the parties, nor, as noted earlier, as an introductory quote. However, the quotation in Ogilvie does illustrate one of the less common and less elegant purposes of poetic quotations - one which I did not discuss in my review. The quotation from Sonnet 116 in the opening line is paired with a quotation from Henry VI Part 1 in the last line where Judge

Edelstein says "make this marriage to be solemniz'd". ${ }^{22}$ I omitted such bookended uses of poetic quotations from my review due to their weak connections with the intervening judgment.

\section{Dean $v$ District of Columbia and Quilter v Attorney-General}

The last two true minds cases that I would like to review are Dean $v$ District of Columbia, an American appeal decision from 1995, and Quilter $v$ Attorney-General, a 1998 decision of the New Zealand Court of Appeal. The facts of the cases are remarkably similar. In Dean, two gay men

21 In the Matter of Keith Ogilvie (1975) 373 NYS 2d 281 (NY Co Ct).

22 In the Matter of Keith Ogilvie above n 21, 283 quoting William Shakespeare Henry VI Part 1 V:iii. 
had applied for a marriage licence and were refused. ${ }^{23}$ In Quilter, three lesbian couples had each applied for a marriage licence and also been refused. ${ }^{24}$

The use of Sonnet 116 is also remarkably similar. In Dean, Associate Judge Terry began the second paragraph of his judgment as follows: ${ }^{25}$

The outcome of this case, in my view, turns on the definition of marriage. Shakespeare in his 116th

Sonnet wrote of "the marriage of true minds". In the game of pinochle, the king and queen of the same suit are referred to as a "marriage" when those cards are held by the same player; if that suit is trump, the combination of king and queen is a "royal marriage." But these and similar expressions are only metaphors, figures of speech derived from the literal meaning of the word that serves as the fulcrum of this case.

A similar, briefer statement appears in Tipping J's judgment in Quilter: ${ }^{26}$

In a sense, Shakespeare voiced the appellants' pleas 400 years ago when he wrote in Sonnet CXVI

"Let me not to the marriage of true minds admit impediments."

In both these cases, I suggest that the reference to "the marriage of true minds" serves an introductory purpose - it sets the tone for the remaining text of the judgment. And it sets the tone somewhat poignantly as in both Tipping J's and Associate Judge Terry's judgments the impediments to the marriages in question are the central issue. And they are impediments that will remain to prevent the marriage of these true minds from becoming a legal marriage. The introductory quotations thus also serve as a comment on the parties - recognising the existence and depth of their relationship, while refusing legal recognition. The sonnet is offered as acceptance that love exists, though the law will not recognise it as a legal tie.

I suggest that it is in cases such as Dean and Quilter that judges have the unique opportunity to experience vicariously what Justice Frankfurter described as "the wonderful mysteries of the universe" - in particular the wonderful mystery that is love. In Dean and Quilter we find individuals who have taken on the State to prove the strength and legitimacy of their love for one another. In comparison, Romeo and Juliet only challenged their own families.

23 Dean and Gill $v$ District of Columbia (1995) 653 A 2d 307 (DCCA).

24 Quilter v Attorney-General [1998] 1 NZLR 523 (CA).

25 Dean and Gill v District of Columbia above n 23, 361.

26 Quilter v Attorney-General above n 24, 572. 
Think what great works could result if there was some way for poets to read the evidence of love that is documented and presented to judges in such cases as Dean and Quilter.

Then poets might instead quote judges.

\section{CONCLUSION}

In conclusion, I would like to return to the poem I began with, WH Auden's "Law Like Love". As the title suggests, Auden compares law to love. But the poem is in fact a doublemetaphor. Not only is law compared to love but love is compared to law, to the point where the two words can be interchanged with each other throughout the poem. If we make that substitution in the present verse, we get a fairly accurate summary of what judges currently say about love.

Love, says the judge as he looks down his nose,

Speaking clearly and most severely,

Love is as I've told you before,

Love is as you know I suppose,

Love is but let me explain it once more,

Love is Love.

Not a verse that offers much potential to unlocking the wonderful mysteries of the universe. And yet judges deal routinely in such things as love. A daily roster comes before them of human conflict and aspirations that would inspire even the most blocked writer. In such an environment, it is no surprise to find that that judges occasionally burst into poetry albeit borrowed verse. The surprise is perhaps that they do not do it more often. And to those of you who are once or future judges, should you find that the opportunity arises, then I encourage you give something back to the poets. And to that end, I leave you with just a few questions about love that Auden has raised in case you find you can answer them. ${ }^{27}$

Does it look like a pair of pyjamas

Or the ham in a temperance hotel,

Does its odour remind one of llamas

Or has it a comforting smell?

Is it prickly to touch as a hedge is

Or soft as eiderdown fluff,

27 WH Auden "Tell Me the Truth About Love" in Collected Poems (Vintage International, New York, 1991). 
Is it sharp or quite smooth at the edges?

O tell me the truth about love. 
